er resultatene sammenlignet med data fra de medisinske registre i våre naboland. Det ville være nærliggende å foreta en sammenligning med våre egne data som forelå og ble presentert i Blindekartotekets oversikter, siste gang ved kartotekets nedleggelse i 1995. Blindekartotekets siste rapport ble sendt til alle landets øyeleger og øyeavdelinger samt til andre institutter. En engelsk versjon ble sendt til institutter og avdelinger i utlandet, og mange positive tilbakemeldinger ble mottatt.

I kartoteket er det innsamlede data fra alle aldersgrupper (2). Totalt blinde og svaksynte i live per 1.1.1995 var 10 077, hvorav 668 var under 20 år. Hele datamaterialet utgjorde ca. 25000 blinde og svaksynte innsamlet gjennom de 27 år som Blindekartoteket var i virksomhet. På grunn av svakheten ved øyelegenes mangelfulle meldinger ble kartotekets data supplert fra andre kilder, først og fremst fra Blindeforbundet, som Blindekartoteket hadde et godt samarbeid med. Ca. $40 \%$ av tilgangen til kartoteket ble fanget opp på denne måten.

En tragisk beslutning om nedleggelse av Blindekartoteket ble gjort av daværende helsedirektør. Saksbehandlingen må betegnes som skandaløst dårlig. Beslutningen om nedleggelse var forhastet og bygd på sviktende premisser. De nærmere omstendigheter omkring nedleggelsen er redegjort for i rapporten (2).

Blindekartoteket, da det var i funksjon, var ganske enestående i verden med obligatorisk melding av alle blinde og svaksynte. En stor svakhet var likevel svikten i meldinger fra øyelegene, til tross for at lovfestet meldeplikt var innført. Det store materialet som er lagret i Blindekartoteket, vil fortsatt være en verdifull basis ved en eventuell gjeninnføring av en øyemedisinsk registrering. Databasen med de identifiserbare meldinger ble overført til Statens helseundersøkelser og Riksarkivet.

Anbefalingene fra Haugen og medarbeidere om gjenopprettelse av et øyemedisinsk register i Norge bør støttes fullt ut. Registrering er uomgjengelig nødvendig for bekjempelse av blindhet og svaksynthet. Man må bare håpe at vanskelighetene som foreligger $\mathrm{i}$ dag, kan overvinnes.

\section{Egill Hansen}

egillh@online.no

Egill Hansen (f. 1929) er spesialist i øyesykdommer og tidligere leder av Blindekartoteket.

Ingen oppgitte interessekonflikter.

\section{Litteratur}

1. Haugen $\mathrm{OH}$, Bredrup C, Rødahl E. Nedsatt syn hos barn og unge i Norge. Tidsskr Nor Legeforen 2016: 136: 996-1000.

2. Hansen E, red. Det norske blindekartotek 1968-1995. Status og oppsummering. Rapport. Oslo: Det norske blindekartotek, 1996.

\section{O.H. Haugen og medarbeidere svarer:}

Vi vil takke tidligere leder for Blindekartoteket Egill Hansen for kommentar til vår artikkel om nedsatt syn hos barn og unge (1) og hans støtte til vårt anliggende. Han etterlyser en sammenlikning av dataene fra studien med data som forelå i Blindekartoteket. I vår artikkel har vi referert grundig til NORDSYN-studien, som jo besto av data samlet fra synsregistrene i Norge, Danmark, Finland og Island. I artiklene fra denne studien ble det vist at funnene fra disse fire landene var ganske samstemte, både når det gjaldt fordeling mellom svaksynte og blinde (2), fordeling på diagnosegrupper (3) og etiologiske faktorer (4). I og med NORDSYN-studien er således data fra Det norske blindekartotek også presentert. Dataene fra vår studie samsvarer, som nevnt i vår artikkel, godt både med NORDSYN-dataene og den tilsvarende svenske studien.

\section{Olav H. Haugen}

olav.haugen@helse-bergen.no

Cecilie Bredrup

Eyvind Rødahl

Olav H. Haugen (f. 1955) er spesialist i øyesykdommer, professor og seksjonsoverlege ved Øyeavdelingen, Haukeland universitetssykehus og Universitetet i Bergen.

Ingen oppgitte interessekonflikter.

Cecilie Bredrup (f. 1973) er spesialist i øyesykdommer og forsker ved Øyeavdelingen, Haukeland universitetssykehus.

Ingen oppgitte interessekonflikter.

Eyvind Rødahl (f. 1957) er spesialist i øyesykdommer og professor ved Øyeavdelingen, Haukeland universitetssykehus og Universitetet i Bergen. Ingen oppgitte interessekonflikter.

\section{Litteratur}

1. Haugen $\mathrm{OH}$, Bredrup C, Rødahl E. Nedsatt syn hos barn og unge i Norge. Tidsskr Nor Legeforen 2016: 136:996-1000.

2. Riise R, Flage T, Hansen E et al. Visual impairment in Nordic children. I. Nordic registers and prevalence data. Acta Ophthalmol (Copenh) 1992; 70: 145-54.

3. Hansen E, Flage T, Rosenberg T et al. Visual impairment in Nordic children. III Diagnoses. Acta Ophthalmol (Copenh) 1992; 70: 597-604.

4. Rosenberg T, Flage T, Hansen E et al. Visual impairment in Nordic children. II. Aetiological factors. Acta Ophthalmol (Copenh) 1992; 70: 155-64. 